\title{
Relationship between Liquidity and Profitability: Empirical Study from the Czech Republic
}

\author{
Jan Svitlik - Lukáš Poutník
}

\begin{abstract}
:
The paper deals with relationship between liquidity and profitability ratios in the Czech Republic to investigate whether there exists correlation (a) within selected liquidity ratios and (b) selected liquidity ratios and selected profitability ratio in the Czech Republic during the period 2003-2013. Empirical data from Bureau van Dijk, Amadeus database were analysed from the point of both time-series and cross-sectional analysis. The main findings of the paper are that correlation within selected liquidity ratios is fairly strong while correlation between selected liquidity ratios and selected profitability ratio is relatively weak.
\end{abstract}

Key words: Liquidity; Profitability; Czech Republic; Empirical study.

JEL classification: M41, G30.

\section{Introduction}

All over the world, financial managers make finance and investment decisions by considering an objective of wealth maximization. A whole range of techniques might be used to maximize revenues or minimize costs. Working capital management basically covers planning and controlling activities of the core business. Basically, the higher the sales are the more working capital have to be maintained by companies. On the other hand, companies endeavour to avoid unnecessary amount of working capital in any form of current assets. Deloof (2003) investigates that efficient working capital management accelerates economic growth and is mainly dependent on profit margin and liquidity. Gill et al (2010) discovers that efficient management of working capital helps the business to achieve optimal level of profit. Several other studies have been conducted to investigate determinants of relationship between working capital (or other liquidity ratios) and profitability ratios. Liquidity is regarded as one of the key factors (e.g. Karaduman et al, 2010). Our paper is primarily focused on the relationship among

\footnotetext{
Jan Svitlík; University of Economics, Prague, Faculty of Finance and Accounting, Department of Financial Accounting and Auditing, Winston Churchilla Square 4, 13067 Prague 3, Czech Republic, <xsvij10@vse.cz>.

Lukáš Poutník; University of Economics, Prague, Faculty of Finance and Accounting, Department of Financial Accounting and Auditing, Winston Churchilla Square 4, 13067 Prague 3, Czech Republic, <lukas.poutnik@gmail.com>.

The article is processed as an output of a research project Relevance of Accounting Information on Consolidated Basis in Business and Public Sector registered by the Grant Agency under the registration number F1/47/2015.
} 
Svitlík, J. - Poutník, L.: Relationship between Liquidity and Profitability: Empirical Study from the Czech Republic.

working capital, liquidity ratios and profitability ratios in the Czech Republic. The objective of this paper is to find, whether there exist correlation (a) within selected liquidity ratios and (b) selected liquidity ratios and selected profitability ratio in the Czech Republic. To achieve this goal, we exploit the access to Bureau van Dijk, Amadeus database and investigated Czech companies during period 20032013.

\section{Literature review}

Bourke (1989) explores a sample of 90 banks in Europe, North America and Australia for the period 1972-1981 and finds positive correlation between liquid assets and profitability in banking sector. Molyneux and Thornton (1992) use regression analysis of 18 European countries between 1986 and 1989. They find significant negative correlation between liquidity and profitability and suggest that cash holding reduces returns as they represent opportunity costs. Sarvanan (2001) conducts study focused on working capital management of selected non-banking financial companies. He concludes that sample firms place more importance on liquidity aspects compared to profitability aspects using several statistical tools and methods. Nathan et al (2001) measures the effect of profitability on current ratio, operating expenses to sales ratio and inventory turnover ratio. He finds that working capital management is essential for profitability improvement. Deloof (2003) conducts study containing over 5,000 Belgian companies during 1992-1996 to determine the effect of working capital management on profit margin of companies and suggests that companies are able to enhance shareholders value by maintaining optimal balance between current assets and current liabilities. Ferreira and Villela (2004) investigates EU countries for the period 1987-2000 to find out why firms hold cash. He suggests that company's size and leverage have negative impact on cash holdings but investments are directly affected by cash holding decisions. The empirical investigation of 839 publicly traded UK companies by Ozkan and Ozkan (2004) shows that liquidity position is determined by company's size, leverage ratio and debt position. Drobetz and Grüninger (2006) take sample of 156 Swiss non-financial companies between 1995 and 2004 to study different motives of cash holding and find nonlinear relationship between companies' cash position and leverage ratio. Pedro (2007) conducts study on 860 small and medium size Spanish companies to investigate the determinants of cash holding. His conclusion is that companies having good terms with credit institutions need to hold less cash to minimize their costs. Ali (2009) investigates relationship of cash conversion cycle (CCC), company size and profitability of 166 trading and manufacturing companies from seven industries in Turkey. The study reveals significant positive correlation between $\mathrm{CCC}$ and return on equity (ROE), and negative correlation between company size, ROA and CCC. On the other hand, Mehmet (2009) investigates 49 Turkish companies between 1993 and 
2007 and finds positive correlation between net working capital and ROA. Karaduman et al (2010) deals with relationship between working capital management and profitability of 140 companies listed on Istanbul Stock Exchange for the period 2005-2008. His study focuses on ROA as a measure of profitability, and maturity of accounts receivable, maturity of accounts payable, inventory and $\mathrm{CCC}$ as measures of working capital management. Correlation and regression analyses show that the variables are positively correlated.

\section{Quantitative characteristics}

Basically, there are two relevant financial statements; income statement which reports revenues and expenses of the company during particular period, and balance sheet that shows assets, liabilities and equity of the company at a given point of time. Balance sheet provides a picture of financial health of the company and, among others, it is a tool used to evaluate liquidity. Income statement enables to measure efficiency of the company and it is necessary to evaluate profitability. Both statements are important for companies to manage financial operations and make well-informed decisions based on facts. In terms of this paper, we exploit information both from balance sheet and income statement to calculate selected profitability and liquidity ratios.

Profitability ratios measure ability of a company to generate profit. In this paper, we use return on assets as the proxy for profitability of a company. An increase in the ratio is viewed as a positive trend. This indicator is relative to company's total assets and shows efficiency of management in using assets to generate earnings. Net income is divided by total assets to calculate return on assets. It is usually displayed as a percentage. (Annemans, 2008).

Liquidity ratios measure capacity of the business to meet short term financial commitments as they become due. We focus on current ratio and quick ratio. Current ratio (also called working capital ratio) is a measure of solvency or liquidity of the business. Current assets divided by current liabilities is the formula of current ratio. The higher the current ratio, the better the capacity to meet short term financial commitments. Current ratio of 2:1 (2.000) is regarded as desirable for a healthy business. As a general rule, it is desirable to achieve current ratio above 1:1 (1.000) and as close to 2:1 (2.000) as possible (Michalski, 2011). Quick ratio is the measure of liquidity of all assets quickly convertible into cash used to meet short term liabilities. Current assets less inventory divided by current liabilities is the formula to calculate quick ratio. Optimal quick ratio is 1:1 or higher which means that current liabilities can be met using current assets without need to sell inventory (Schroeder et al, 2011).

Working capital which shows assets necessary to fund day-to-day operations of a business, is the difference between current assets and current liabilities. We 
Svitlík, J. - Poutník, L.: Relationship between Liquidity and Profitability: Empirical Study from the Czech Republic.

calculate so called working capital turnover, as working capital divided by turnover, to provide comparable ratio no matter of company size.

\section{Data and methodology}

We exploit the access to Bureau van Dijk, Amadeus database to follow micro backward-looking methodology and undertake both time-series and cross-sectional empirical research of selected liquidity and profitability ratios in the Czech Republic. The initial sample from the database consists of 400,304 firm-years from 2003 to 2013. The time span has been defined as the broadest period available from the database of Czech companies. Initial sample was adjusted as follows in the way not to bias the results. We keep only 12-months financial year data of active firms. Joint stock companies (a.s.) and limited liability companies (s.r.o.) are kept in the sample, other forms of business were dropped. Firms-years with missing or zero values of total assets (TA), current assets (CA), stocks (inventory), current liabilities (CL), earnings after tax (EAT) or operating turnover (TURN) were dropped. Firm-years with negative values of TA, CA, CL or turnover were dropped as well. Then we dropped financial and insurance sector firms (NACE 6400-6699) because these institutions usually have different business characteristics. As in the last step, the sample was trimmed at $5 \%$ level (two-tailed) to eliminate outliers. Details concerning initial sample selection are described in Tab. 1. Final sample breakdown to financial years and economic sectors (according to NACE) follow in Tab. 2 and Tab. 3 which both prove balanced distribution of firm-years in time and among economic sectors. 
Tab. 1: Sample adjustments

Sample adjustment

Initial sample

Only active firms kept

Only 12-months fin. years kept

Only joint stock companies and limited liability companies kept

Missing values (TA, CA, Stocks, CL, EAT, Turnover)

Zero values (TA, CA, Stocks, CL, EAT, Turnover)

Negative values (TA, CA, CL, Turnover)

Financial institutions dropped

Outliers elimination (trimmed at 5\% level two-tailed)

Final sample
Number of firm-years

400,304

$-9,576$

$-907$

$-75,236$

$-34,624$

$-10,088$

$-841$

$-1,112$

$-26,792$

241,128

Source: authorial computation using Bureau van Dijk, Amadeus database (2015).

Tab. 2: Breakdown of the final sample: financial years

\begin{tabular}{lr} 
Financial year & Number of firm-years \\
\hline 2003 & 3,440 \\
2004 & 0,000 \\
2005 & 18,910 \\
2006 & 21,519 \\
2007 & 24,657 \\
2008 & 27,317 \\
2009 & 28,987 \\
2010 & 29,998 \\
2011 & 30,605 \\
2012 & 30,143 \\
2013 & 25,552
\end{tabular}

Source: authorial computation using Bureau van Dijk, Amadeus database (2015). 
Svitlík, J. - Poutník, L.: Relationship between Liquidity and Profitability: Empirical Study from the Czech Republic.

\section{Tab. 3: Breakdown of the final sample: economic sectors}

\begin{tabular}{|c|c|c|}
\hline Name of the economic sector & NACE ${ }^{1}$ & Number of firm-years \\
\hline Agriculture, forestry and fishing & $01-03$ & 10,299 \\
\hline Mining and quarrying & $05-09$ & 688,000 \\
\hline Manufacturing & $10-33$ & 65,782 \\
\hline Electricity, gas, steam and air conditioning supply & 35 & 3,163 \\
\hline $\begin{array}{l}\text { Water supply; sewerage; waste management and } \\
\text { remediation activities }\end{array}$ & $36-39$ & 3,571 \\
\hline Construction & $41-43$ & 27,280 \\
\hline $\begin{array}{l}\text { Wholesale and retail trade; repair of motor vehicles and } \\
\text { motorcycles }\end{array}$ & $45-47$ & 60,912 \\
\hline Transporting and storage & $49-53$ & 11,599 \\
\hline Accommodation and food service activities & $55-56$ & 6,421 \\
\hline Information and communication & $58-63$ & 8,254 \\
\hline Financial and insurance activities & $64-66$ & 0,000 \\
\hline Real estate activities & 68 & 8,380 \\
\hline Professional, scientific and technical activities & $69-75$ & 15,514 \\
\hline Administrative and support service activities & $77-82$ & 9,044 \\
\hline $\begin{array}{l}\text { Public administration and defense; compulsory social } \\
\text { security }\end{array}$ & 84 & 26,000 \\
\hline Education & 85 & 2,717 \\
\hline Human health and social work activities & $86-88$ & 4,357 \\
\hline Arts, entertainment and recreation & $90-93$ & 1,929 \\
\hline Other activities & 94-99 & 1,192 \\
\hline
\end{tabular}

Source: authorial computation using Bureau van Dijk, Amadeus database (2015).

${ }^{1}$ NACE abbreviation stands for statistical classification of economic activities in the European Community. We use first two out of four digits of NACE to determine the most general economic classification in the Czech Republic. 


\section{Time-series analysis}

We provide both time-series and cross-sectional analysis of selected liquidity and profitability ratios in the paper. We focus namely on current ratio (CR), quick ratio $(\mathrm{QR})$ and working capital turnover (WCT) as the proxies for liquidity characteristics of the company, and return on assets (ROA) as the proxy for profitability.

\subsection{Liquidity and profitability ratios time-series analysis}

As mentioned in quantitative characteristics, companies generally aim to achieve current ratio around 2.0 or higher. We find that mean current ratio in the Czech Republic was higher than 2.0 in all examined years. Mean quick ratio was higher than 1.0 (and even higher than 2.0) during the whole period which confirms our findings. Except for 2005, when mean current ratio and mean quick ratio were extremely high, both ratios show stable, slightly upward trend in the Czech Republic.

Working capital turnover, the last investigated proxy for liquidity of Czech companies, indicates slightly increasing trend over the period 2003-2013. All three liquidity ratios suggest that companies in the Czech Republic are willing to hold more current assets compared to current liabilities over time. Nevertheless, the change is not significant.

Return on assets fluctuated between 2,1\% and 7,3\% during 2003-2013 with the exception of 2010 when profitability increased rapidly to $40 \%$.

These results suggest, on the one hand, fairly high correlation within selected liquidity ratios, and on the other hand, insignificant correlation between liquidity and profitability ratios. 
Svitlík, J. - Poutník, L.: Relationship between Liquidity and Profitability: Empirical Study from the Czech Republic.

\section{Fig. 1: Current ratio}

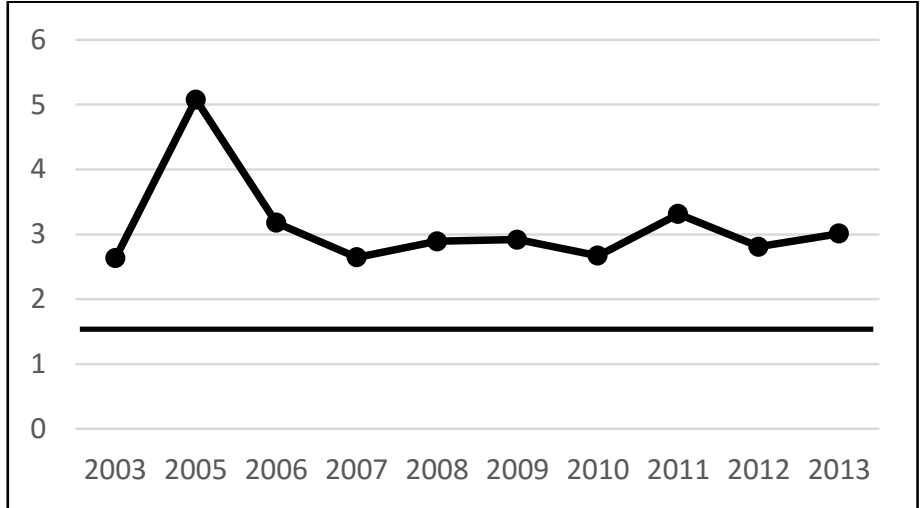

Source: authorial computation using Bureau van Dijk, Amadeus database (2015).

\section{Fig. 2: Quick ratio}

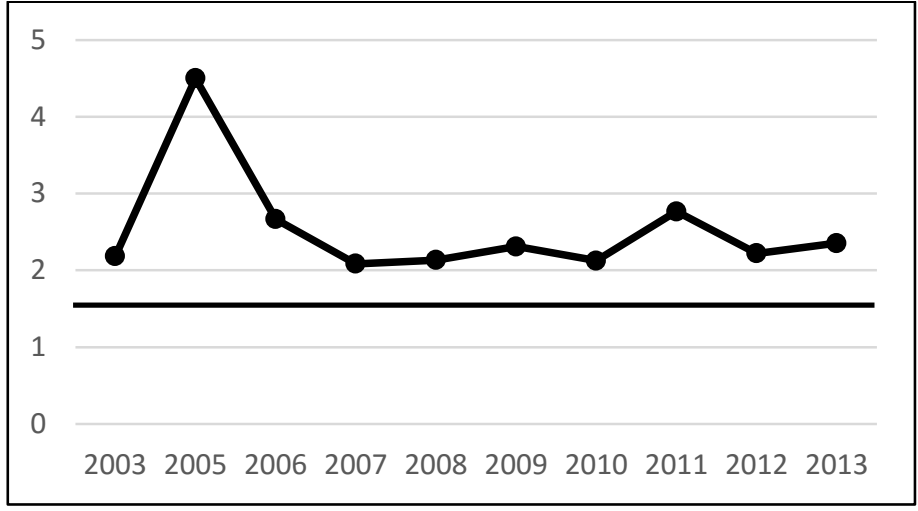

Source: authorial computation using Bureau van Dijk, Amadeus database (2015). 


\section{Fig. 3: Working capital turnover}

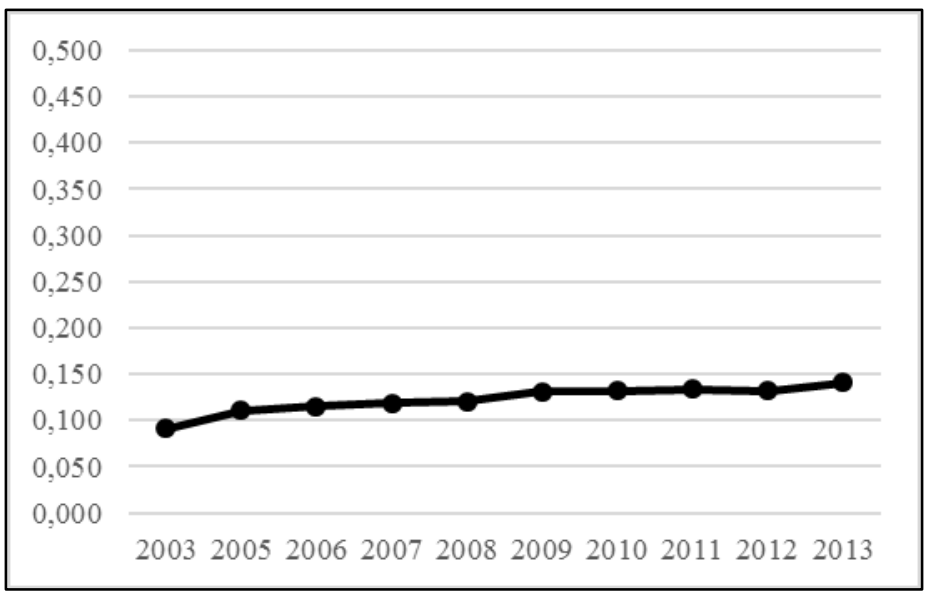

Source: authorial computation using Bureau van Dijk, Amadeus database (2015).

\section{Fig. 4: Return on assets}

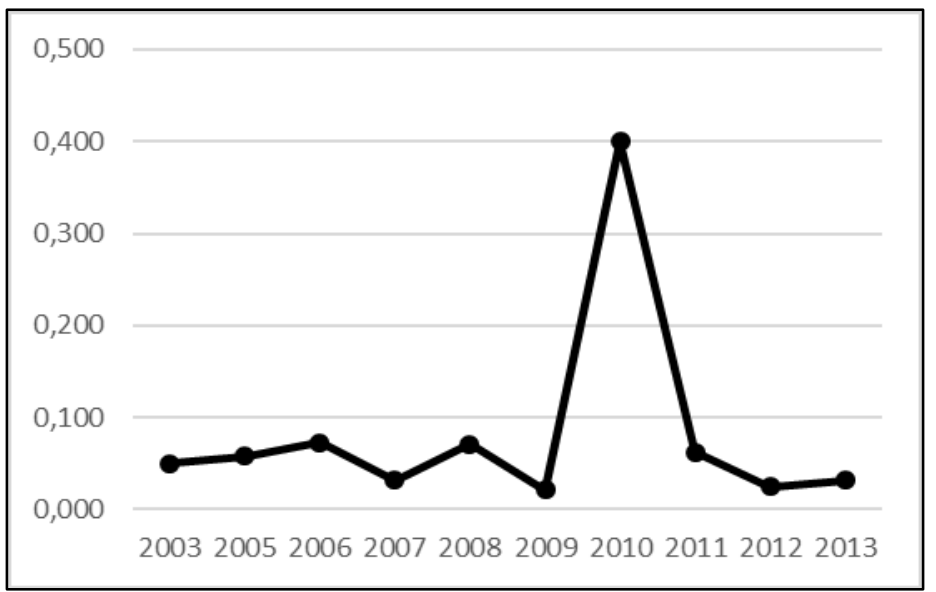

Source: authorial computation using Bureau van Dijk, Amadeus database (2015). 
Svitlík, J. - Poutník, L.: Relationship between Liquidity and Profitability: Empirical Study from the Czech Republic.

\subsection{Time-series analysis of correlations}

As the second step of time-series analysis, we run regressions and find Pearson's correlation coefficients to confirm or reject, whether there exists statistically significant correlation between selected ratios. Four graphs below depict correlation coefficients between selected ratios. Correlation between current ratio and quick ratio is very strong during all period which suggests relatively low proportion of inventory on current assets of Czech companies. The correlation coefficient never dropped under $97 \%$ during 2003-2013. On the other hand, correlation of current ratio (quick ratio) and working capital turnover never exceeded $19 \%$ from 2003 until 2013. Except for 2006, the correlation is statistically significant but relatively weak. See Fig. 5-8 for details.

In terms of return on assets, there is statistically significant correlation only between working capital turnover and return on assets; except for 2007, 2008 and 2011, when we are able to find no correlation between selected ratios at all. These findings suggest that, if there is any, the correlation between profitability and liquidity ratios is rather weak.

\section{Fig. 5: Capital ratio $x$ Working capital turnover}

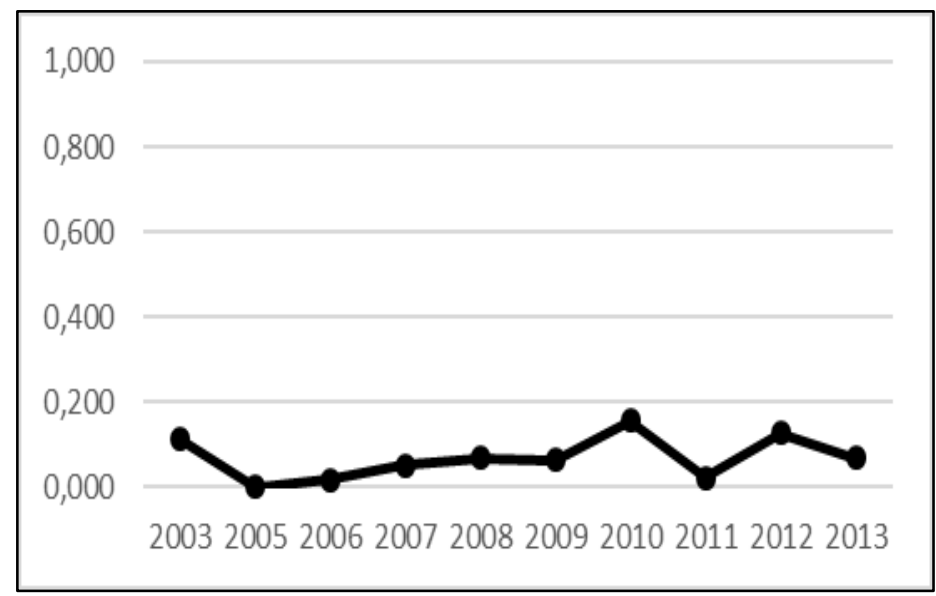

Source: authorial computation using Bureau van Dijk, Amadeus database (2015). 
Fig. 6: Quick ratio x Working capital turnover

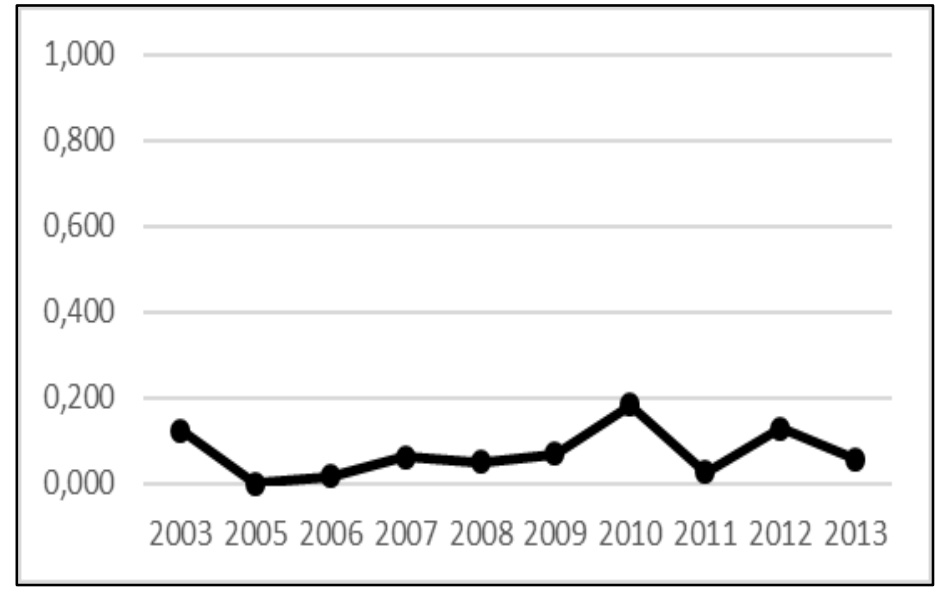

Source: authorial computation using Bureau van Dijk, Amadeus database (2015).

\section{Fig. 7: Current ratio x Quick ratio}

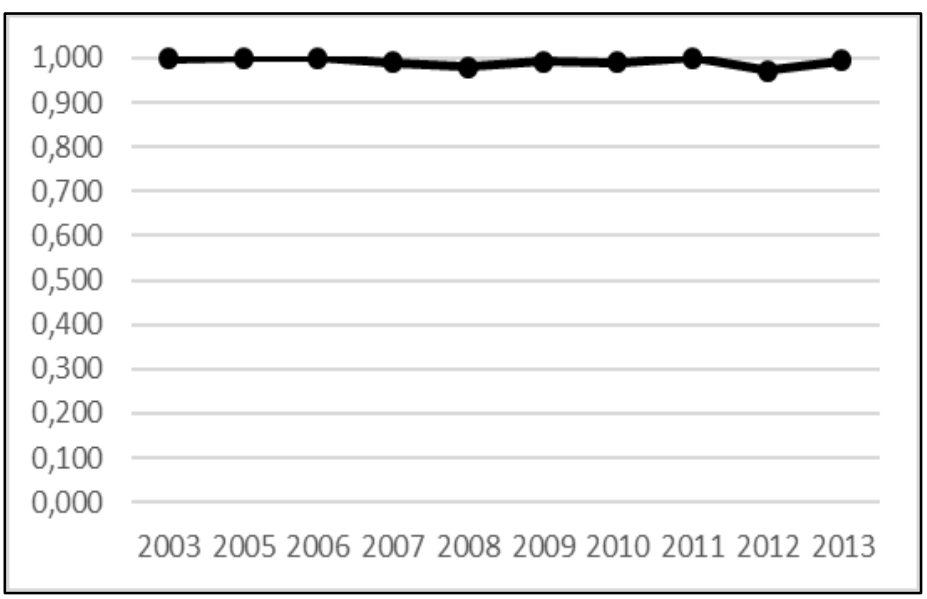

Source: authorial computation using Bureau van Dijk, Amadeus database (2015). 
Svitlík, J. - Poutník, L.: Relationship between Liquidity and Profitability: Empirical Study from the Czech Republic.

\section{Fig. 8: Return on assets $x$ Working capital turnover}

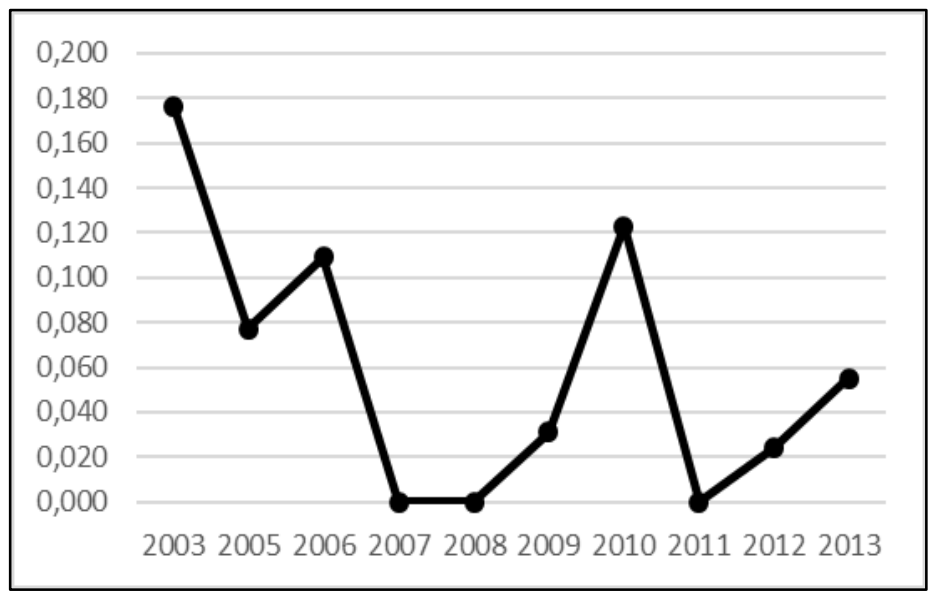

Source: authorial computation using Bureau van Dijk, Amadeus database (2015).

\section{Cross-sectional analysis}

We also investigate cross-sectional analysis of the selected ratios in the Czech Republic during 2003-2013. Three different analyses were conducted based on economic sectors, consolidated vs. unconsolidated data basis and a company size.

\subsection{Economic sectors analysis}

All final data sample of 241,128 firm-years was divided into economic sectors according to NACE and we investigated both mean value of ratios among economic sectors and ratios correlations among economic sectors. Tab. 4 shows mean ROA, mean CR, mean QR and mean WCT in columns 3-6. The same data for mean CR, mean QR and mean WCT are provided in the fig. 9-11 (see below). We find mean current ratio over 1.7 within all economic sectors in the Czech Republic. Most of the sectors indicate mean current ratio between 2.0 and 4.0 which means a relatively high one.

Mean quick ratio within all economic sectors is over 1.5 and mostly between 2.0 and 3.5. Thus, mean quick ratio is relatively high in the Czech Republic as well.

Mean working capital turnover ranges from $-1,8 \%$ (Accommodation and food service activities) to $28.2 \%$ (Public administration and defence; compulsory social security). This finding indicates significant differences among economic sectors in case of percentage of working capital on turnover of the company.

In additional tests we find statistically significant correlation among all selected liquidity ratios (CR, QR, WCT) within all economic sectors (see column 8 in tab. 4). On the other hand, correlation between selected liquidity ratios and ROA was 
not found within all economic sectors. We find statistically significant correlation between ROA and WCT within most of the economic sectors. Correlation between ROA and CR (and similarly ROA and QR) exists in roughly half of the economic sectors in the Czech Republic.

These findings confirm our time-series analysis findings as we find statistically significant correlation within three selected liquidity ratios, but the correlation between selected liquidity ratios and ROA is rather weak.

Tab. 4: Economic sectors analysis

\begin{tabular}{|c|c|c|c|c|c|c|c|}
\hline NACE & $\begin{array}{l}\text { Number } \\
\text { of firm } \\
\text { years }\end{array}$ & ROA & CR & QR & WCT & $\begin{array}{l}\text { ROA } x \text { liquidity } \\
\text { ratios correlation } \\
(95 \% \text { conf. level })\end{array}$ & $\begin{array}{l}\text { CR x QR x WCT } \\
\text { correlation } \\
(95 \% \text { conf. level })\end{array}$ \\
\hline $01-03$ & 10,299 & 0.033 & 3.768 & 2.192 & 0.261 & Yes & Yes \\
\hline 05-09 & 688,000 & 0.054 & 2.825 & 2.354 & 0.185 & Yes & Yes \\
\hline $10-33$ & 65,782 & 0.049 & 2.653 & 1.939 & 0.134 & ROA x WCT only & Yes \\
\hline 35 & 3,163 & 0.032 & 4.054 & 3.944 & 0.130 & No & Yes \\
\hline $36-39$ & 3,571 & 0.055 & 3.123 & 2.854 & 0.168 & ROA x WCT only & Yes \\
\hline $41-43$ & 27,280 & 0.044 & 2.328 & 2.048 & 0.120 & ROA x WCT only & Yes \\
\hline $45-47$ & 60,912 & 0.066 & 4.059 & 3.097 & 0.117 & ROA x WCT only & Yes \\
\hline $49-53$ & 11,599 & 0.023 & 3.571 & 3.486 & 0.068 & ROA x WCT only & Yes \\
\hline $55-56$ & 6,421 & -0.153 & 1.889 & 1.652 & -0.018 & ROA x WCT only & Yes \\
\hline $58-63$ & 8,254 & 0.100 & 2.303 & 2.134 & 0.156 & Yes & Yes \\
\hline $64-66$ & 0,000 & - & - & - & - & - & - \\
\hline 68 & 8,380 & -0.044 & 3.654 & 3.276 & 0.122 & No & Yes \\
\hline $69-75$ & 15,514 & 0.078 & 2.613 & 2.430 & 0.168 & Yes & Yes \\
\hline $77-82$ & 9,044 & 0.061 & 2.532 & 2.415 & 0.109 & Yes & Yes \\
\hline 84 & 26,000 & 0.115 & 3.065 & 2.977 & 0.292 & ROA x QR only & Yes \\
\hline 85 & 2,717 & -0.021 & 1.708 & 1.670 & 0.044 & Yes & Yes \\
\hline $86-88$ & 4,357 & 0.079 & 3.578 & 3.491 & 0.106 & ROA x WCT only & Yes \\
\hline $90-93$ & 1,929 & -0.019 & 2.402 & 2.299 & 0.091 & Yes & Yes \\
\hline $94-99$ & 1,192 & 0.029 & 3.182 & 2.820 & 0.093 & Yes & Yes \\
\hline
\end{tabular}

Source: authorial computation using Bureau van Dijk. Amadeus database (2015). 
Svitlík, J. - Poutník, L.: Relationship between Liquidity and Profitability: Empirical Study from the Czech Republic.

\section{Fig. 9: Current ratio}

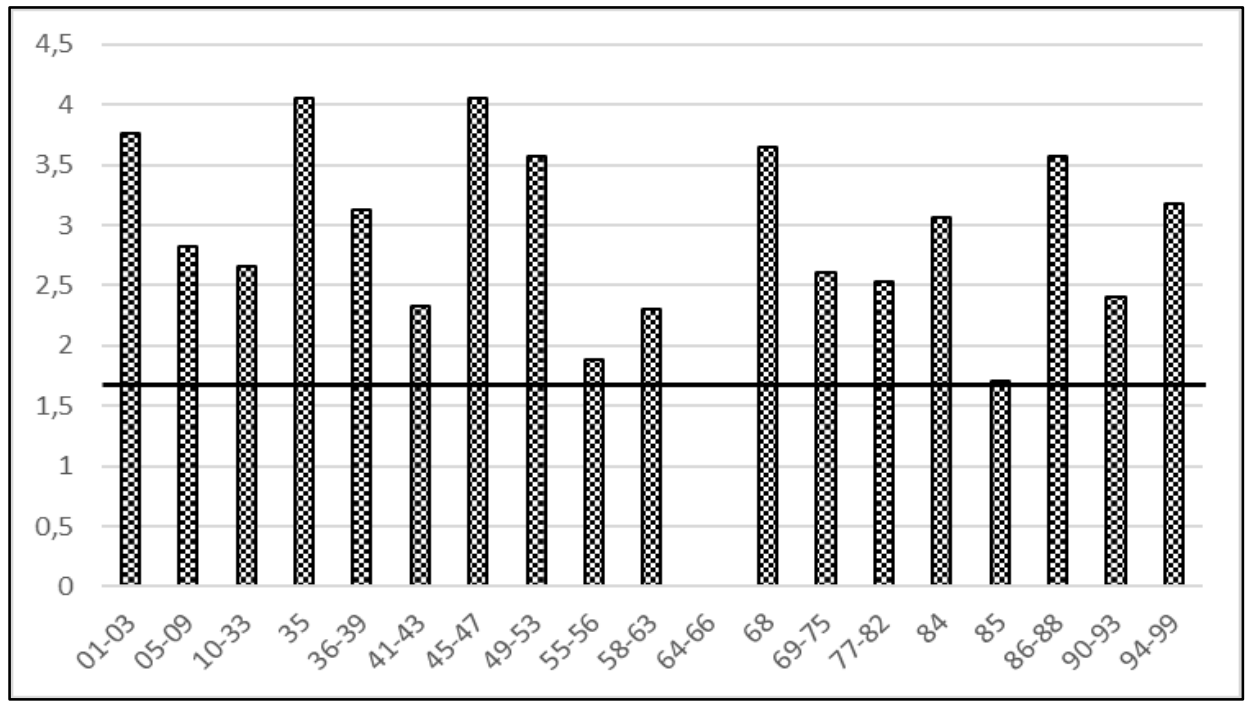

Source: authorial computation using Bureau van Dijk, Amadeus database (2015).

\section{Fig. 10: Quick ratio}

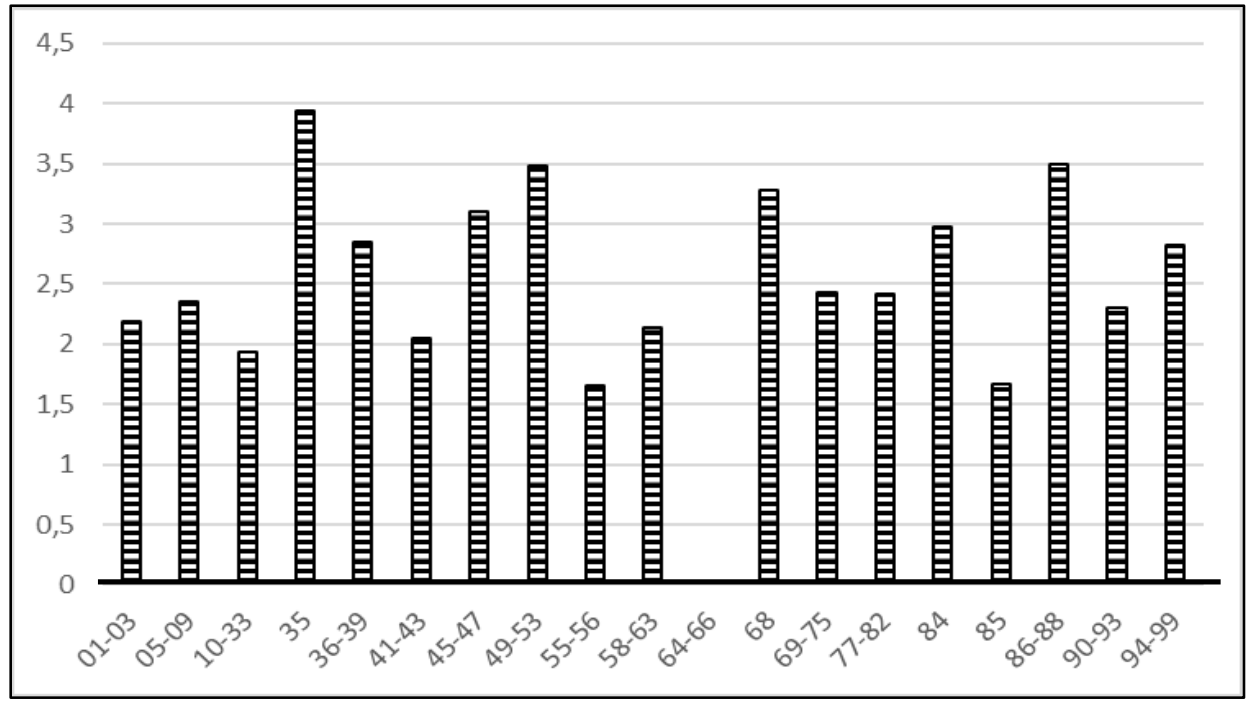

Source: authorial computation using Bureau van Dijk, Amadeus database (2015). 


\section{Fig. 11: Working capital turnover}

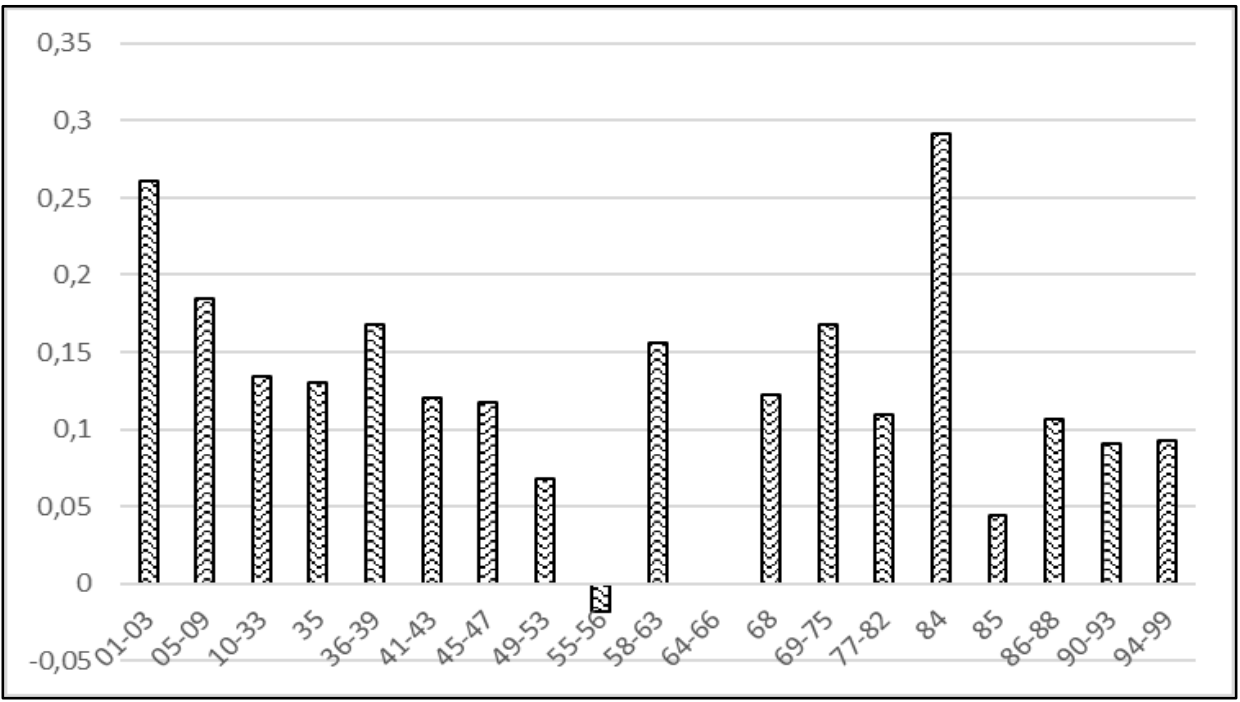

Source: authorial computation using Bureau van Dijk, Amadeus database (2015).

\subsection{Consolidated vs. unconsolidated data analysis}

The second part of our cross-sectional data analysis focuses on the comparison of consolidated and unconsolidated data. Tab. 5 shows our findings. Correlation between $\mathrm{CR}$ and $\mathrm{QR}$ is strong in case of both consolidated and unconsolidated data bases. We find the difference regarding correlation between CR and WCT (similarly QR and WCT); in case of consolidated data, there is statistically significant and relatively strong correlation between these ratios, on the other hand, there is still statistically significant but rather weak correlation in case of unconsolidated data.

The only statistically significant correlation between liquidity ratios and ROA is in case of ROA and WCT, where we find statistically significant but relatively weak correlation within both consolidated and unconsolidated data.

In disarranged tests we investigated companies reporting under IFRS and companies reporting under Czech GAAP. We find similar correlation characteristics of as for consolidated vs. unconsolidated data analysis. Namely, IFRS reporting companies show similar characteristics to companies reporting on consolidated basis and Czech GAAP reporting companies indicate similar characteristics to unconsolidated companies. 
Svitlík, J. - Poutník, L.: Relationship between Liquidity and Profitability: Empirical Study from the Czech Republic.

Tab. 5: Consolidated vs. unconsolidated data analysis

\begin{tabular}{lll} 
& Consolidated data & Unconsolidated data \\
\hline CR x QR & strong & strong \\
CR x WCT & relatively strong & weak \\
QR x WCT & relatively strong & weak \\
ROA x WCT & relatively weak & weak \\
ROA x CR & no & no \\
ROA x QR & no & no \\
\hline
\end{tabular}

Source: authorial computation using Bureau van Dijk, Amadeus database (2015).

\subsection{Company size analysis}

As the last step of the cross-sectional analysis, we focus on company size tests. See the results in tab. 6 .

We find statistically significant correlation between $\mathrm{CR}$ and $\mathrm{QR}$ within all company-size categories. Also our findings concerning CR and WCT (and similarly QR and WCT) are alike for very large, large and medium sized companies, where we find statistically significant but relatively weak correlation between given ratios.

In case of ROA, as the proxy for profitability, there is statistically significant correlation between all selected liquidity ratios only within the category of very large companies. Still the correlation is weak according to Pearson's correlation coefficient. Regarding large companies and medium sized companies, we find statistically significant (weak) correlation only between ROA and CR.

\section{Results and conclusion}

Both time-series and cross-sectional analysis of Czech companies during the period 2003-2013 gives us very similar results. We find relatively strong correlation within selected ratios, namely current ratio, quick ratio and working capital turnover. This finding is very important as it enables future authors to use just one of these ratios as the proxy for liquidity characteristics of a company. Particularly current ratio and quick ratio are highly correlated in the Czech Republic which suggests relatively low proportion of inventories on current assets. This basically holds for various years, various economic sectors, consolidated and unconsolidated data basis and different company-size categories. We also find statistically significant, although relatively weak, correlation between current ratio (quick ratio similarly) and working capital turnover for all investigated years, economic sectors, data bases and company-size categories. 
In terms of profitability and liquidity correlation, we are unable to confirm statistically significant correlation between selected liquidity ratios and return on assets as the proxy for profitability. On the one hand, we find statistically significant correlation between return on assets and working capital turnover for most of the years, most of the economic sectors, both consolidated and unconsolidated data and very large companies. On the other hand, the correlation is relatively weak in all the cases. Moreover, there is no statistically significant correlation between current ratio (quick ratio similarly) and return on assets for any investigated year and about half of economic sectors. All in all, if there exists any relation between liquidity and profitability of a company, the correlation is rather weak in the Czech Republic

\section{References}

Ali, U., 2009. The Relationship of Cash Conversion Cycle with Firm Size and Profitability: An Empirical Investigation in Turkey. International Research Journal of Finance and Economics 24, 6-16.

Annemans, N., 2008. An Introduction to the Concepts, Methods and Pitfalls of Health Economic Evaluations. Health Economics for Non-Economists, Gent, Academia Press.

Bourke, P., 1989. Concentration and Other Determinants of Bank Profitability in Europe, North America and Australia. Journal of Banking \& Finance 1, 65-79. DOI: 10.1016/0378-4266(89)90020-4.

Deloof, M., 2003. Does Working Capital Management Affect Profitability of Belgian Firms? Journal of Business, Finance and Accounting 3\&4, 573-587. DOI: 10.1111/1468-5957.00008.

Drobetz, W., Grüninger, M., 2006. Corporate Cash Holdings: Evidence from Switzerland. WWF Forschungsbericht 7, 1-35. DOI: 10.1007/s11408-007-0052-8.

Ferreira, M. A., Vilela, A. S., 2004. Why Do Firms Hold Cash? Evidence from EMU Countries. European Financial Management 2, 295-319. DOI: 10.1111/j.1354-7798.2004.00251.x.

Gill, A., Biger, N., Mathur, N., 2010. The Relationship Between Working Capital Management and Profitability: Evidence from the United States. Business and Economics Journal 1.

Karaduman, H. A., Akbas, H. E., Ozsozgun, A., Salih, D., 2010. Effects of Working Capital Management on Profitability: The Case for Selected Companies in the Istanbul Stock Exchange (2005-2008). International Journal of Economics and Finance Studies 2, 47- 54. 
Svitlík, J. - Poutník, L.: Relationship between Liquidity and Profitability: Empirical Study from the Czech Republic.

Mehmet, S., 2009. Relationship Between Efficiency Level of Working Capital Management and Return on Total Assets in ISE. International Journal of Business and Management 10, 109-114. DOI: 10.5539/ijbm.v4n10p109.

Michalski, G. M., 2011. Financial Analysis in the Firm: A Value- Based Liquidity Framework. Available from: <http://ssrn.com/abstract=1839367>. [13 February 2016].

Molyneux, P., Thornton, J., 1992. Determinants of European Bank Profitability. Journal of Banking and Finance 6, 1173-1178. DOI: 10.1016/03784266(92)90065-8.

Nathan, S., Sivakumar, K., Vijayakumar, J., 2001. Returns to Trading Strategies Based on Price-to-Earnings and Price-to-Sales Ratios. The Journal of Investing 2, 17-28. DOI: 10.3905/joi.2001.319458.

Ozkan, A., Ozkan, N., 2004. Corporate Cash Holdings: An Empirical Investigation of UK Companies. Journal of Banking and Finance 9, 2103-2134. DOI: 10.1016/j.jbankfin.2003.08.003.

Pedro, J. G., Pedro, M. S., 2007. Effect of Working Capital Management on SME Profitability. International Journal of Managerial Finance 2, 164-177. DOI: 10.1108/17439130710738718.

Saravanan, P., 2001. A study on working capital management in non banking finance companies. Finance India 3, 30-45.

Schroeder, R., Clarc, M., Cathey, J. M., 2011. Financial Accounting Theory and Analysis. New Jersey, John Wiley \& Sons. 